IZA DP No. 9536

Hiring a Homosexual, Taking a Risk?

A Lab Experiment on Employment Discrimination and Risk Aversion

Stijn Baert

November 2015 


\title{
Hiring a Homosexual, Taking a Risk? A Lab Experiment on Employment Discrimination and Risk Aversion
}

\author{
Stijn Baert \\ Ghent University, University of Antwerp, \\ Université catholique de Louvain and IZA
}

Discussion Paper No. 9536

November 2015

\author{
IZA \\ P.O. Box 7240 \\ 53072 Bonn \\ Germany \\ Phone: +49-228-3894-0 \\ Fax: +49-228-3894-180 \\ E-mail: iza@iza.org
}

Any opinions expressed here are those of the author(s) and not those of IZA. Research published in this series may include views on policy, but the institute itself takes no institutional policy positions. The IZA research network is committed to the IZA Guiding Principles of Research Integrity.

The Institute for the Study of Labor (IZA) in Bonn is a local and virtual international research center and a place of communication between science, politics and business. IZA is an independent nonprofit organization supported by Deutsche Post Foundation. The center is associated with the University of Bonn and offers a stimulating research environment through its international network, workshops and conferences, data service, project support, research visits and doctoral program. IZA engages in (i) original and internationally competitive research in all fields of labor economics, (ii) development of policy concepts, and (iii) dissemination of research results and concepts to the interested public.

IZA Discussion Papers often represent preliminary work and are circulated to encourage discussion. Citation of such a paper should account for its provisional character. A revised version may be available directly from the author. 
IZA Discussion Paper No. 9536

November 2015

\section{ABSTRACT \\ Hiring a Homosexual, Taking a Risk? A Lab Experiment on Employment Discrimination and Risk Aversion*}

We investigate risk aversion as a driver of labour market discrimination against homosexual men. We show that more hiring discrimination by more risk-averse employers is consistent with taste-based and statistical discrimination. To test this hypothesis we conduct a scenario experiment in which experimental employers make a hiring decision concerning a heterosexual or homosexual job candidate. In addition, participants are surveyed on their risk aversion and other characteristics that might correlate with this risk aversion. Analysis of the (post-)experimental data confirms our hypothesis. The probability of a beneficial hiring decision for homosexual candidates decreases by $31.7 \%$ when employers are a standard deviation more risk-averse.

JEL Classification: $\quad$ C91, J15, J71

Keywords: $\quad$ hiring discrimination, statistical discrimination, sexual orientation, scenario experiment, risk aversion

Corresponding author:

Stijn Baert

Ghent University

Sint-Pietersplein 6

9000 Gent

Belgium

E-mail: Stijn.Baert@UGent.be

\footnotetext{
* The author gratefully acknowledges Sandy Van Laer and Nathalie Verhaeghe for their research assistance.
} 


\section{Introduction}

Employing comprehensive field experiments, during the past decade scholars have shown that discrimination is still a barrier for (openly) homosexual job candidates in the labour market. The most convincing evidence in this respect has been provided by so-called correspondence experiments. In these experiments, fictitious job applications, differing only in a randomly assigned engagement in pro-gay organisations, are sent in response to real job openings. By monitoring the subsequent call-back rate from employers, unequal treatment based on this signal of homosexual orientation is identified and can be given a causal interpretation (Pager, 2007; Riach \& Rich, 2002). Between 2005 and 2012, correspondence experiments to measure hiring discrimination against homosexuals were conducted in five different countries. The level of discrimination appeared to differ substantially by country. Fictitious homosexual job candidates received $12 \%$ fewer positive call-backs than equal applicants revealing no such engagement in Sweden in 2011-2012 (Ahmed, Andersson \& Hammarstedt, 2013), 30\% fewer positive callbacks in Italy in 2012 (Patacchini, Ragusa \& Zenou, 2015), 37\% fewer positive callbacks in the United States in 2005 (Tilcsik, 2011), 65\% fewer positive call-backs in Greece in 2006-2007 (Drydakis, 2009) and 73\% fewer positive call-backs in Cyprus in 2010-2011 (Drydakis, 2014). ${ }^{1}$ This unequal treatment is not only unacceptable from an ethical perspective but also has important economic consequences (Baert, 2014; Ng, Schweitzer \& Lyons, 2012).

Identifying discrimination is one thing; tackling it is another. To effectively combat labour market discrimination against sexual minorities, one needs to understand its driving factors. In other words, to design adequate policy actions, targeted to the right employers in the right way, one has to gain insight into which

\footnotetext{
${ }^{1}$ In addition, lower levels of hiring discrimination against lesbian job candidates were found in Cyprus and Greece (Drydakis, 2011; Drydakis, 2014). In Sweden and Belgium, revealing a lesbian sexual orientation did not affect employment opportunities overall (Ahmed et al., 2013; Baert, 2014). In the latter country, for women in their fertile years, a positive effect of revealing a lesbian sexual orientation was even found.
} 
employers discriminate against homosexuals and why these employers discriminate against them. One key factor by which discrimination might be heterogeneous is employers' risk aversion. In this study, we are the first to investigate the link between hiring discrimination against homosexuals and this risk aversion. First, based on the leading theoretical models of labour market discrimination, we predict higher levels of discrimination by risk-averse employers. Subsequently, employing a scenario experiment, we test this prediction empirically.

\section{Theoretical Predictions}

In spite of the development of alternative approaches to theorising labour market discrimination, ${ }^{2}$ the leading economic theories in this respect, especially in the case of sexual orientation discrimination, are still Becker's (1957) model of taste-based discrimination and Arrow's (1973) model of statistical discrimination (Baert, 2014; Guryan \& Charles, 2013). In this section, we show that both theories support a positive relationship between labour market discrimination - both in general and in particular against homosexual job candidates - and the risk aversion of employers.

\subsection{Taste-Based Discrimination}

Taste-based discrimination blinds employers to the (true) monetary costs associated with hiring a minority worker. Following this theory, employers who discriminate will, due to the disutility they experience by interacting with such a minority worker, act as if the costs of hiring this worker exceed its actual costs. Becker's (1957) "discrimination coefficient" provides the mark-up on the costs of

\footnotetext{
2 Interesting alternatives for the models of taste-based and statistical discrimination are the models of implicit discrimination (Altonji \& Blank, 1999), lexicographic search by employers (Bertrand \& Mullainathan, 2004) and non-competing groups (Darity \& Mason, 1998).
} 
hiring a minority worker attributable to employers' prejudice. Analogously, prejudiced co-workers may act as if the wage they obtain from their employer is lower by a fraction equal to their discrimination coefficient if they have to interact with a minority worker. Finally, customers might act as if the price of the good they want to buy is higher by a fraction equal to their discrimination coefficient in that case. Even when they are not prejudiced themselves, profit-maximising employers will take the prejudices of their employees and customers into account when deciding on whether or not to hire a minority worker. As a consequence, regardless of whether the source of the prejudice is the employer himself ("employer discrimination"), his employees ("employee discrimination") or his customers ("customer discrimination"), taste-based unequal treatment will decrease the likelihood of being hired for the minority worker (Baert, 2014; Becker, 1957; Borjas, 2009; Drydakis, 2014).

Analogous to the general case, taste-based discrimination against homosexuals could be caused by employers', employees' and customers' general distaste for sexual minorities and their experienced disutility of interacting with homosexuals, lesbians, bisexuals and transgenders. However, with respect to employee discrimination and customer discrimination, employers have to make their hiring decisions based on their perception of their employees' and customers' distaste for interacting with homosexual workers. As a consequence, hiring a homosexual job candidate is, in respect of these employers, a risk, i.e., a risk of creating trouble on the work floor and discomfort among their customers. As a result, risk-averse employers might be less willing to hire homosexuals.

\subsection{Statistical Discrimination}

Statistical discrimination occurs when, as a time-efficient and profit-maximising response to low information and uncertainty about the actual productivity of individual job candidates, employers take into account their perception about the relative productivity-related characteristics of minorities as a group (based on information that might be imperfect) to predict a particular minority applicant's 
productivity (Arrow, 1973; Baert, 2014; Borjas, 2009; Charles \& Guryan, 2008).

Initially, scholars focussed on first-order statistical discrimination, i.e., unequal treatment based on (perceived) group differences in their average productivityrelated characteristics. In this respect, the fact that homosexuals are perceived as, on average, less dominant, autonomous and assertive, might be a source of (statistical) discrimination, as dominance, autonomy and assertiveness are associated with labour market success (Berg \& Lien, 2002; Blandford, 2003).

More recent contributions, however, have focussed on second-order statistical discrimination, i.e., unequal treatment based on (perceived) group differences in the variance of their productivity-related characteristics (Dickinson \& Oaxaca, 2009; Dickinson \& Oaxaca, 2014; Klumpp \& Su, 2013; Neumark, 2012). This perceived variance is usually assumed - and empirically found - to be higher among minority workers, potentially because (majority dominated) employers are less familiar with these workers (Baert, Cockx, Gheyle \& Vandamme, 2015; Carlsson, Fumarco \& Rooth, 2014; Dickinson \& Oaxaca, 2014; Neumark, 2012). For risk-averse employers, however, a less risky productivity distribution (i.e., a distribution with a lower variance) is preferred to a more risky distribution. As a consequence, risk-averse employers may hesitate to hire homosexuals based on their higher (perceived) productivity variance, even though their (perceived) average productivity may be identical to that of their heterosexual counterparts. Thus, also based on the theory of statistical discrimination, a positive relationship between employers' risk aversion and their discriminatory behaviour is expected.

\section{Method}

To test the relationship between hiring discrimination and risk aversion empirically, we conducted a lab experiment. This experiment extends the scenario experiment Baert \& De Pauw (2014) proposed to test the empirical importance of general attitudes underlying the aforementioned models of taste-based and statistical 
discrimination in explaining ethnic hiring discrimination.

In the present section, we describe the conducted experiment and provide the reader with summary statistics of the resulting data.

\subsection{Experiment}

We recruited 222 participants from an undergraduate economics class at Ghent University in Flanders, the northern Dutch-speaking region of Belgium, in September 2015.

These participants first received a booklet containing experimental instructions. At the beginning of this booklet, testers were introduced to their role as employer at a company selling building materials. This company was in search of a new counter assistant. The testers were informed that this counter assistant should be (i) customer-oriented, (ii) service-minded and (iii) commercially oriented. In addition, the assistant was expected to be efficient and reliable in managing administrative tasks.

Subsequently, the participants were asked to screen the resume of a fictitious job candidate for this position as counter assistant. This resume showed a male candidate from Ghent, the second-largest city in Flanders, with the right qualifications. More concretely, this candidate had left school in June 2008 holding a secondary education degree in accountancy and informatics. From the summer of 2008 onwards, he had worked as a commercial clerk at a (non-existing) firm. In addition, this candidate had the following characteristics: Belgian nationality, Dutch mother tongue, excellent English and French language skills, good German language skills and extensive computer skills (office applications).

The only aspect in which the resumes provided to the participants differed (i.e., the experimental manipulation) was the name of the spouse of the candidate 
(mentioned in the resume's personal section and preceded by "Married to"). ${ }^{3}$ The names "Jonas Van Damme" (a typical male Flemish name) and "Julie Van Damme" (a typical female Flemish name) were alternately assigned to the resumes. ${ }^{4}$ This approach contrasts with the aforementioned field studies on sexual orientation discrimination, in which homosexual candidates signalled their sexual orientation by disclosing an engagement in a pro-gay organisation. In line with Baert (2014), we believe that our approach has two advantages. First, sexual orientation is signalled in a more direct way. Second, the negative impact of perceived activism signalled by involvement in a pro-gay organisation is avoided.

Based on this information, the participants were asked to perform two tasks. First, they had to fill out a manipulation check. In this check we tested their perception of the sexual orientation (and, not to give away the aim of the experiment, also the sex, residence and origin) of the applicant. Second, the testers were asked to state their intention to hire by scoring the statement "The probability with which I will hire this candidate is high" on a 7-point Likert scale.

\subsection{Post-Experimental Survey}

Immediately after making their hiring decision, participants had to complete a post-experimental survey. On the one hand, we gathered information concerning their level of risk aversion. On the other hand, we surveyed the participants on characteristics that could correlate with this risk aversion and with their distaste for homosexual job candidates: their social desirability bias, their social background and their political ideology.

First, concerning our measure of risk aversion, two subscales of three items each from the Domain-Specific Risk-Taking Scale (Blais \& Weber, 2006) were selected and combined. We chose the subscales measuring "social risk

\footnotetext{
${ }^{3}$ Several real-life recruiters confirmed that including one's spouse's name in one's resume together with one's marital status is not uncommon in Belgium.

${ }^{4}$ Same-sex marriage was legalised in Belgium in 2003.
} 
preferences" and "financial risk preferences," as we considered these particular subscales to be the most relevant in the context of labour market behaviour. Within these subscales, respondents are asked to indicate the likelihood with which they would engage in activities such as "Speaking your mind about an unpopular issue in a meeting at work" and "Investing 5\% of your annual income in a very speculative stock." All scale items were scored on a 7-point Likert scale. Afterwards, the reversed item scores were averaged yielding a global score for risk aversion between 1 and 7 .

Second, the social desirability bias of the participants was measured by means of the short form of the Marlowe-Crowne social desirability scale developed by Reynolds (1982), one of the most used instruments for measuring social desirability (Sârbescu, Costea \& Rusu, 2012). It comprises 13 items that express a behaviour that is culturally sanctioned or approved (for instance, "No matter who I'm talking to, I'm always a good listener"), and participants have to indicate whether these statements apply to them or not. Each socially desirable answer yields one point. In our application, we averaged these scores yielding a global score for socially desirable behaviour beteen 0 and 1 .

Third, the participants' social background was captured by means of five items: their gender (female or male), their age, their nationality (Belgian or non-Belgian), their mother's highest level of education (lower than secondary education, secondary education, tertiary education outside college or tertiary education at college) and their father's highest level of education (same categories as those with respect to their mother).

Finally, their political ideology was measured using the short version of the right-wing authoritarianism scale proposed by Zakrisson (2005) comprising 15 statements that measure participants' degree of willingness to conform to established and legitimate authorities. An example of such a statement is, "Our country desperately needs a mighty leader who will do what has to be done to destroy the radical new ways and sinfulness that are ruining us." All scale items had 
to be scored on a 7-point Likert scale yielding, by averaging all item scores, a global score for right-wing authoritarianism between 1 and 7 .

\subsection{Data Description}

Table 1 describes the data gathered during the experiment and post-experimental survey described in the former two subsections. In this table, we compare the average values for the manipulation check, the hiring decision and the participant characteristics of the two subsamples of participants classified by the sexual orientation of their assigned job candidate.

$<$ Table 1 about here. $>$

Panel A shows that our experimental manipulation worked. Obviously, there is a highly significant difference in perception of the job candidates the two subsamples got as being heterosexual.

Next, Panel B shows that, on average, hiring decisions did not vary by the sexual orientation of the applicants. This overall finding is consistent both with the tolerant public opinion towards sexual minorities in Belgium, as reflected in Eurobarometer (2006) - the country had an openly homosexual Prime Minister between 2011 and 2014 - and the finding of no hiring discrimination against lesbian workers in Baert (2014) mentioned in footnote $1 .^{5}$

Finally, Panel $\mathrm{C}$ shows that the randomisation of sexual orientation over the testers worked. Both groups of testers are very similar in terms of risk aversion, social desirability bias, gender, age, nationality, parental education level and rightwing authoritarianism. Concerning the internal consistency of the used scales, Cronbach's alpha-coefficient is 0.593 for the risk aversion scale, 0.657 for the social desirability bias scale and 0.603 for the right-wing authoritarianism scale.

\footnotetext{
${ }^{5}$ We are not aware of any field experiment measuring hiring discrimination against homosexual men in Belgium.
} 


\section{Data Analysis}

In this section, we present a regression analysis aimed at testing our hypothesis of more unfavourable treatment of homosexual job candidates when employers are more risk-averse. More concretely, we conduct probit regressions. The dependent variable of these regressions is an indicator of an intention to hire score that is 6 or 7 (and thereby higher than the average values presented in Panel B of Table 1). ${ }^{6}$

Table 2 displays our regression results presented as marginal effects. In regression models (1) to (5), we regress the aforementioned binary dependent variable on a gradually expanding set of variables. These variables are included as such and in interaction with the homosexual orientation of the job candidate the participants had to screen. For reasons of regression results comparability, all variables except for the one indicating homosexual orientation are normalised (the binary variables) or standardised (the continuous (scale) variables).

<Table 2 about here.>

In model (1), we regress the intention to hire on a dummy indicating homosexual orientation only. We find that the probability of a high likelihood of hiring is 6.3 percentage points higher for homosexual candidates. However, in line with the empirical pattern in Panel B of Table 1, we find that this marginal effect is not significantly different from 0 .

Next, in model (2), we add two variables: the scale indicating the risk aversion of the experimental employer and this scale interacted with the homosexual orientation of the fictitious job candidate, i.e., the variable of main interest. The marginal effect for this interaction variable is -0.147 , thus indicating that the probability of a beneficial hiring outcome is $\mathbf{1 4 . 7}$ percentage points lower for

\footnotetext{
${ }^{6}$ Logit regressions on the same dependent variable yield the same conclusions. The same is true for ordered logit regressions and linear regressions with heteroscedastic-consistent standard errors with the experimental employers' intention to hire as scored on a 7-point Likert scale (and, thereby, going from 1 to 7) as a dependent variable. The results for these regression models are available on request.
} 
homosexual candidates when employers are one standard deviation more riskaverse. This marginal effect is significantly different from 0 at the $5 \%$ significance level. Thereby, model (2) confirms our research hypothesis.

In addition, the marginal effect for the risk aversion scale without interaction with the homosexual orientation of the job candidate is 0.151 , which is significantly different from 0 at the $1 \%$ significance level. This means that the overall probability of a positive hiring outcome is 15.1 percentage points higher when employers are one standard deviation more risk-averse, ${ }^{7}$ ceteris paribus.

Finally, in models (3) to (5) we include additional variables (as such and in interaction with the homosexual orientation of the job candidate) that might correlate with the risk aversion of our experimental employers. As these variables might evenly correlate with their hiring decisions, not including these variables in model (2) might have resulted in biased estimates for this model. In model (3), we include the social desirability bias scale; in model (4), indicators for employers of male gender and employers with at least one parent with a tertiary level of education (obtained in or outside of college) are added; ${ }^{8}$ and in model (5), the right-wing authoritarianism scale is included.

Interestingly, the inclusion of these additional variables increases the magnitude of the marginal effect of main interest. Model (5) indicates that, after including all of these additional variables, the relative likelihood of a beneficial hiring outcome is 16.3 percentage points lower for homosexual candidates when employers are one standard deviation more risk-averse. Compared to an average probability of obtaining a high intention to hire score of $51.4 \%$ for homosexual candidates, this implies a decrease in this probability by $31.7 \%$ when employers are a standard deviation more risk-averse. ${ }^{9}$

\footnotetext{
${ }^{7} \mathrm{~A}$ standard deviation corresponds to a 0.806 difference on the 7-point Likert risk aversion scale.

8 The variables capturing the age and nationality of the candidates do not exhibit enough variation to be added to the regression model. In addition, the adoption of alternative proxies for the parental education level lead to the same conclusion.

${ }^{9} 0.317=0.163 / 0.514$.
} 
In addition, in line with our a priori expectations given the aforementioned culturally approved tolerance towards sexual minorities in Belgium, we find that participants with a higher tendency toward socially desirable answering provide homosexual candidates with more beneficial hiring outcomes. This suggests that the adoption of this variable is relevant for future experiments on discrimination (in particular against homosexuals).

\section{Conclusion and Discussion}

Large-scale field studies have shown that in various OECD countries, homosexual job candidates receive fewer positive call-backs than their heterosexual counterparts. To combat this labour market discrimination against sexual minorities, one needs to understand its driving factors. In this study, we investigated the relationship between discrimination against homosexual men by employers on the one hand and these employers' level of risk aversion on the other hand. First, we showed that more hiring discrimination by employers who are more risk-averse is consistent with the seminal discrimination theories of Becker (1957) and Arrow (1973). Then, to test this theoretical expectation empirically, we conducted a scenario experiment in which participants, in their role as employer, had to make a hiring decision concerning a job candidate whose sexual orientation was indicated by revealing the name of his spouse in his resume. In addition, we surveyed the participants on their risk aversion, using two validated (sub)scales and other characteristics that might be correlated with their risk aversion: their socially desirable behaviour, their social background and their political ideology. A regression analysis based on these (post-)experimental data confirmed our research hypothesis. The probability of a beneficial hiring decision for homosexual candidates decreased by $31.7 \%$ when employers were a standard deviation more risk-averse. In addition, from a methodological point of view, we underlined the importance of controlling for socially desirable behaviour in 
discrimination experiments.

This study contributes to several literatures. First, it complements the abovementioned field experiments on hiring discrimination against homosexuals in Europe and North America. While these field experiments show, in a compelling way, that discrimination is still a struggle for homosexuals in the labour market, they do not provide evidence on the mechanisms underlying this unequal treatment. In fact, the only study of which we are aware that focusses on these mechanisms is the work of Drydakis (2014), who tests the empirical importance of key attitudes underlying the models of taste-based and statistical discrimination in the context of sexual orientation discrimination. Second, we contribute to the recent (but still scarce) empirical research on the mechanisms underlying employment discrimination in general (see, for instance, Baert \& De Pauw, 2014; Fuentes-Fuentes, Bojica, Ruiz-Arroyo \& Welter, Forthcoming; Midtbøen, 2014; Nunley, Pugh, Romero \& Seals, 2015; Zussman, 2013). Third, while some recent contributions have studied risk aversion on the employee side as an explanation for (gender) inequality in the labour market (see, for instance, Hartford \& Spearman, 2014), we are not aware of studies, other than the present one, directly testing the effect of risk aversion on the employer side as an explanation for inequality in the labour market. Finally, as mentioned above, risk aversion is in particular related to second-order statistical discrimination, i.e., unequal treatment based on the (perceived) higher variance of the productivity distribution of minority groups. As a result, our study can also be seen as a contribution to the booming literature on this second-order statistical discrimination (Dickinson \& Oaxaca, 2014; Klumpp \& Su, 2013; Neumark, 2012).

Our research shows that unfavourable hiring outcomes of homosexual job candidates can be tackled by lowering the perceived risk related to hiring these candidates. Therefore, policy makers might consider awareness campaigns that highlight success stories of (open) homosexuals in the workplace. Because prejudices are formed at an early age, it might be a good idea to integrate such campaigns into education. In addition, from an individual job candidate's 
perspective, our results teach us that homosexual men have every interest in providing employers with as much information as possible to dispel any uncertainty about their productivity (and, ipso facto, any perceived risk related to hiring them). They could, in this respect, consider including extended motivation letters and reference letters in their job applications demonstrating their professional ambition.

Our empirical research is limited by its laboratory setting. However, the success of scenario studies in fields such as sociology and psychology is related to the fact that self-report measures of perceptions have been shown to correlate highly with actual behaviour and that changes in intentions clearly result in actual behavioural changes. Moreover, a scenario experiment addresses some limitations of other experimental approaches, which have been criticised for making too much abstraction of real life situations, thereby raising questions about the external validity or generalisability of their findings. This is the case as the use of a scenario allows us to describe the context in which participants define their intentions more realistically while establishing valid causal relationships (Baert \& De Pauw, 2014; Colquitt, 2008; De Dreu, Evers, Beersma, Kluwer \& Nauta, 2001; Mook, 1983; Shadish, Cook \& Campbell, 2002; Van Hoye \& Lievens, 2003; Webb \& Sheeran, 2006).

Another limitation is related to the fact we engaged students (and not real recruiters) as experimental employers. However, Hosoda, Stone-Romero \& Coats (2003) and Falk, Meier \& Zehnder (2013) show that, in general and in particular with respect to screening job candidates, students' ratings are practically identical to those of professional recruiters. Moreover, student participants are less likely to respond in a socially desirable manner (probably because they are less worried about the reputation of the profession of recruiter). Lastly, students in an undergraduate economics class could be thought of as tomorrow's employers.

As a last limitation, we have to acknowledge that Cronbach's alpha-coefficient for the risk aversion scale we used was rather low. However, the (sub)scales we 
employed are amongst the most used instruments for measuring risk aversion in the academic literature. Nevertheless, the construction of scales that can more effectively capture potential mechanisms underlying employment discrimination, including key attitudes underlying the models of taste-based and statistical discrimination, is necessary for the further elucidation of these mechanisms. As aforementioned, gaining a better insight into these mechanisms is a condition sine qua non to designing adequate anti-discrimination policies.

\section{References}

Ahmed, A., Andersson, L., \& Hammarstedt, M. (2013). Are Gay Men and Lesbians Discriminated against in the Hiring Process? Southern Economic Journal, 79, 565585.

Altonji, J., Blank, R. (1999). Race and Gender in the Labor Market. In O. Ashenfelter, \& D. Card (Eds.), Handbook of Labor Economics. Amsterdam: Elsevier.

Arrow, K.J. (1973). The theory of discrimination. In O. Ashenfelter, \& A. Rees (Eds.), Discrimination in Labor Markets. Princeton: Princeton University Press.

Baert, S. (2014). Career Lesbians. Getting Hired for Not Having Kids? Industrial Relations, 45, 543-561.

Baert, S., Cockx, B., Gheyle, N., \& Vandamme, C. (2015). Is There Less Discrimination in Occupations Where Recruitment Is Difficult? Industrial \& Labor Relations Review, 68, 467-500.

Baert, S., \& De Pauw, A.-S. (2014). Is Ethnic Discrimination due to Distaste or Statistics? Economics Letters, 125, 270-273.

Becker, G.S. (1957). The Economics of Discrimination. Chicago: University of Chicago Press.

Berg, N., \& Lien, D. (2002). Measuring the effect of sexual orientation on 
income: evidence of discrimination. Contemporary Economic Policy, 20, 394-414.

Bertrand, M., \& Mullainathan, S. (2004). Are Emily and Greg more employable than Lakisha and Jamal? A field experiment on labor market discrimination. American Economic Review, 94, 991-1013.

Blais, A.-R., \& Weber, E. (2006). A domain-specific risk-taking (DOSPERT) scale for adult populations. Judgment and Decision Making, 1, 33-47.

Blandford, J.M. (2003). The nexus of sexual orientation and gender in the determination of earnings. ILR Review, 56, 622-642.

Borjas, G. (2009). Labor Economics. New York: McGraw-Hill.

Carlsson, M., Fumarco, L., \& Rooth, D.-O. (2014). Does the design of correspondence studies influence the measurement of discrimination? IZA Journal of Migration, 3, 11.

Charles, K.K., \& Guryan, J. (2008). Prejudice and wages: an empirical assessment of Becker's The Economics of Discrimination. Journal of Political Economy, 116, 773-809.

Colquitt, J.A. (2008). From the editors: Publishing laboratory research in AMJ: A question of when, not if. Academy of Management Journal, 51, 616-620.

Darity, W.A., \& Mason, P.L. (1998). Evidence on Discrimination in Employment: Codes of Color, Codes of Gender. Journal of Economic Perspectives, 12, 63-90.

De Dreu, C.A.W., Evers, A., Beersma, B., Kluwer, E.S., \& Nauta, A. (2001). A theory-based measure of conflict management strategies in the workplace. Journal of Organizational Behavior, 22, 645-668.

Dickinson, D.L., \& Oaxaca, R.L. (2006). Statistical Discrimination in Labor Markets: An Experimental Analysis. Southern Economic Journal, 76, 16-31.

Dickinson, D.L., \& Oaxaca, R.L. (2014). Wages, Employment, and Statistical Discrimination: Evidence from the Laboratory. Economic Inquiry, 52, 1380-1391.

Drydakis, N. (2009). Sexual orientation discrimination in the labour market. 
Labour Economics, 16, 364-372.

Drydakis, N. (2011). Women's Sexual Orientation and Labor Market Outcomes in Greece. Feminist Economics, 17, 89-117.

Drydakis, N. (2014). Sexual orientation discrimination in the Cypriot labour market. Distastes or uncertainty? International Journal of Manpower, 35, 720-744.

Eurobarometer. (2006). Public Opinion in the European Union. Standard Eurobarometer, Wave 66. Brussels: European Commission.

Falk, A., Meier, S., \& Zehnder, C. (2013). Do lab experiments misrepresent social preferences? The case of self-selected student samples. Journal of the European Economic Association, 2, 743-771.

Fuentes-Fuentes, M., Bojica, A., Ruiz-Arroyo, M., \& Welter, F. (Forthcoming). Innovativeness and business relationships in women-owned firms: The role of gender stereotypes. Canadian Journal of Administrative Sciences. DOI: 10.1002/cjas.1329.

Guryan, J., \& Charles, K.K. (2013). Taste-Based or Statistical Discrimination: The Economics of Discrimination Returns to its Roots. Economic Journal, 123, 417-432.

Hartford, J., \& Spearman, N. (2014). Who's Afraid of the Big Bad Wolf? Risk Aversion and Gender Discrimination in Assessment. ERSA working paper, 418.

Hosoda, M., Stone-Romero, E.F., \& Coats, G. (2003). The effects of physical attractiveness on job-related outcomes: A meta-analysis of experimental studies. Personnel Psychology, 56, 431-462.

Klumpp, T., \& Su, X. (2013). Second-order statistical discrimination. Journal of Public Economics, 97, 108-116.

Midtbøen, A. H. (2014). The Invisible Second Generation? Statistical Discrimination and Immigrant Stereotypes in Employment Processes in Norway. Journal of Ethnic and Migration Studies, 40, 1657-1675.

Mook, D.G. (1983). In defense of external invalidity. American Psychologist, 5, 
379-387.

Neumark, D. (2012). Detecting Discrimination in Audit and Correspondence Studies. Journal of Human Resources, 47, 1128-1157.

Ng, E.S., Schweitzer, L., \& Lyons, S.T. (2012). Anticipated discrimination and a career choice in non-profit: A study of early career Lesbian, Gay, Bisexual, Transgendered (LGBT) Job Seekers. Review of Public Personnel Administration, 32, 332-352.

Nunley, J.M., Pugh, A., Romero, N., \& Seals, R.A (2015). Racial Discrimination in the Labor Market for Recent College Graduates: Evidence from a Field Experiment. B.E. Journal of Economic Analysis \& Policy, 15, 1093-1125.

Pager, D. (2007). The use of field experiments for studies of employment discrimination: contributions, critiques, and directions for the future. Annals of the American Academy of Political and Social Science, 609, 104-133.

Patacchini, E., Ragusa, G., \& Zenou, Y. (2015). Unexplored dimensions of discrimination in Europe: homosexuality and physical appearance. Journal of Population Economics, 28, 1045-1073.

Reynolds, W.M. (1982). Development of reliable and valid short forms of the Marlowe-Crowne Social Desirability Scale. Journal of Clinical Psychology, 38, 119125.

Riach, P.A., \& Rich, J. (2002). Field Experiments of Discrimination in the Market Place. Economic Journal, 112, 480-518.

Sârbescu, P., Costea, I., \& Rusu, S. (2011). Psychometric properties of the Marlowe-Crowne Social Desirability Scale in a Romanian sample. Procedia - Social and Behavioral Sciences, 33, 707-711.

Shadish, W.R., Cook, T.D., \& Campbell, D. T. (2002). Experimental and quasiexperimental designs for generalized causal inference. Boston: Houghton Mifflin.

Tilcsik, A. (2011). Pride and Prejudice: Employment Discrimination against 
Openly Gay Men in the United States. American Journal of Sociology, 117, 586626.

Van Hoye, G., \& Lievens, F. (2003). The Effects of Sexual Orientation or Hirability Ratings: An Experimental Study. Journal of Business and Psychology, 18, 15-30.

Webb, T.L., \& Sheeran, P. (2006). Does changing behavioral intentions engender behavior change? A Meta-Analysis of the Experimental Evidence. Psychological Bulletin, 132, 249-268.

Zakrisson, I. (2005). Construction of a short version of the Right-Wing Authoritarianism (RWA) scale. Personality and Individual Differences, 39, 863-872.

Zussman, S. (2013). Ethnic Discrimination: Lessons from the Israeli Online Market for Used Cars. Economic Journal, 123, 433-468. 
Table 1

Summary Statistics of the Experimental Data

\begin{tabular}{|c|c|c|c|}
\hline & (1) & $(2)$ & (3) \\
\hline & \multicolumn{2}{|c|}{ Mean } & \multirow{3}{*}{$\begin{array}{l}\text { Difference: } \\
\qquad(2)-(1)\end{array}$} \\
\hline & $\begin{array}{l}\text { Heterosexual } \\
\text { applicant }\end{array}$ & $\begin{array}{l}\text { Homosexual } \\
\text { applicant }\end{array}$ & \\
\hline & $N=111$ & $N=111$ & \\
\hline \multicolumn{4}{|l|}{ A. Manipulation check } \\
\hline $\begin{array}{l}\text { "The candidate has a heterosexual } \\
\text { orientation." }\end{array}$ & 6.200 & 1.477 & $-4.723 * * *[26.194]$ \\
\hline \multicolumn{4}{|l|}{ B. Intention to hire } \\
\hline $\begin{array}{l}\text { "The probability with which I will hire this } \\
\text { candidate is high." }\end{array}$ & 5.360 & 5.441 & $0.081[0.536]$ \\
\hline \multicolumn{4}{|l|}{ C. Participant characteristics } \\
\hline Risk aversion scale & 4.041 & 4.150 & $0.110[1.016]$ \\
\hline Social desirability bias scale & 0.529 & 0.545 & $0.016[0.563]$ \\
\hline Male gender & 0.261 & 0.243 & $-0.018[0.308]$ \\
\hline Age & 18.694 & 18.289 & $-0.405[1.186]$ \\
\hline Foreign nationality & 0.054 & 0.018 & $-0.036[1.441]$ \\
\hline \multicolumn{4}{|l|}{ Highest diploma mother } \\
\hline Lower than secondary education & 0.045 & 0.054 & $0.009[0.308]$ \\
\hline Secondary education & 0.297 & 0.261 & $-0.036[0.596]$ \\
\hline Tertiary education: outside college & 0.405 & 0.468 & $0.063[0.945]$ \\
\hline Tertiary education: college & 0.252 & 0.216 & $-0.036[0.632]$ \\
\hline \multicolumn{4}{|l|}{ Highest diploma father } \\
\hline Lower than secondary education & 0.055 & 0.091 & $0.036[1.036]$ \\
\hline Secondary education & 0.418 & 0.309 & $-0.109 *[1.685]$ \\
\hline Tertiary education: outside college & 0.236 & 0.264 & $0.027[0.465]$ \\
\hline Tertiary education: college & 0.291 & 0.336 & $0.045[0.724]$ \\
\hline Right-wing authoritarianism scale & 3.386 & 3.421 & $0.026[0.351]$ \\
\hline
\end{tabular}

Notes: All statements and scale items were scored on a 7-point Likert scale. T-tests are performed to test whether the differences presented in column (3) are significantly different from zero. ${ }^{* * *}\left({ }^{* *}\right)\left(\left({ }^{*}\right)\right)$ indicates significance at the $1 \%(5 \%)((10 \%))$ significance level. t-statistics are between brackets. 
Table 2

The Intention to Hire by Homosexual Orientation of the Candidate and Risk Aversion of the Employer: Probit Regression Estimates

\begin{tabular}{|c|c|c|c|c|c|}
\hline & (1) & (2) & (3) & (4) & (5) \\
\hline Homosexual applicant & $\begin{array}{c}0.063 \\
(0.067)\end{array}$ & $\begin{array}{c}0.054 \\
(0.068)\end{array}$ & $\begin{array}{c}0.052 \\
(0.068)\end{array}$ & $\begin{array}{c}0.051 \\
(0.069)\end{array}$ & $\begin{array}{c}0.047 \\
(0.069)\end{array}$ \\
\hline $\begin{array}{l}\text { Homosexual applicant x Risk aversion } \\
\text { scale (standardised) }\end{array}$ & & $\begin{array}{c}-0.147^{* *} \\
(0.071)\end{array}$ & $\begin{array}{c}-0.177^{* *} \\
(0.074)\end{array}$ & $\begin{array}{c}-0.169 * * \\
(0.074)\end{array}$ & $\begin{array}{c}-0.163^{* *} \\
(0.075)\end{array}$ \\
\hline $\begin{array}{l}\text { Homosexual applicant x Social } \\
\text { desirability bias scale (standardised) }\end{array}$ & & & $\begin{array}{c}0.140 * * \\
(0.070)\end{array}$ & $\begin{array}{l}0.137 * \\
(0.071)\end{array}$ & $\begin{array}{l}0.136^{*} \\
(0.071)\end{array}$ \\
\hline $\begin{array}{l}\text { Homosexual applicant x Male gender } \\
\text { (normalised) }\end{array}$ & & & & $\begin{array}{c}0.009 \\
(0.163)\end{array}$ & $\begin{array}{c}0.022 \\
(0.163)\end{array}$ \\
\hline $\begin{array}{l}\text { Homosexual applicant x Parent with } \\
\text { tertiary education (normalised) }\end{array}$ & & & & $\begin{array}{c}0.028 \\
(0.167)\end{array}$ & $\begin{array}{c}0.004 \\
(0.169)\end{array}$ \\
\hline $\begin{array}{l}\text { Homosexual applicant x Right-wing } \\
\text { authoritarianism scale (standardised) }\end{array}$ & & & & & $\begin{array}{l}-0.049 \\
(0.071)\end{array}$ \\
\hline Risk aversion scale (standardised) & & $\begin{array}{c}0.151^{* * *} \\
(0.056)\end{array}$ & $\begin{array}{c}0.179 * * * \\
(0.059)\end{array}$ & $\begin{array}{c}0.172 * * * \\
(0.060)\end{array}$ & $\begin{array}{c}0.167^{* * *} \\
(0.060)\end{array}$ \\
\hline $\begin{array}{l}\text { Social desirability bias scale } \\
\text { (standardised) }\end{array}$ & & & $\begin{array}{l}-0.080 \\
(0.050)\end{array}$ & $\begin{array}{r}-0.087^{*} \\
(0.051)\end{array}$ & $\begin{array}{l}-0.086^{*} \\
(0.051)\end{array}$ \\
\hline Male gender (normalised) & & & & $\begin{array}{l}-0.189 \\
(0.116)\end{array}$ & $\begin{array}{l}-0.201^{*} \\
(0.117)\end{array}$ \\
\hline $\begin{array}{l}\text { Parent with tertiary education } \\
\text { (normalised) }\end{array}$ & & & & $\begin{array}{l}-0.003 \\
(0.110)\end{array}$ & $\begin{array}{c}0.022 \\
(0.114)\end{array}$ \\
\hline $\begin{array}{l}\text { Right-wing authoritarianism scale } \\
\text { (standardised) }\end{array}$ & & & & & $\begin{array}{c}0.054 \\
(0.053)\end{array}$ \\
\hline Observations & 222 & 222 & 222 & 222 & 222 \\
\hline
\end{tabular}

Notes: The presented statistics are marginal effects with standard errors between parentheses. ${ }^{* * *}\left({ }^{* *}\right)((*))$ indicates significance at the $1 \%(5 \%)((10 \%))$ significance level. The dependent variable is 1 if the intention to hire score is 6 or 7 and 0 otherwise. The independent variables "Male gender" and "Parent with tertiary education" are normalised by subtracting their mean value. The independent variables "Risk aversion scale", "Social desirability bias scale" and "Right-wing authoritarianism scale" are standardised by subtracting their mean value and dividing the result by these variables' standard deviation. 